\title{
Factors Related Participation of Informal Sector Community to Join the National Health Insurance Programs
}

\author{
Edi Surya ${ }^{1}$ and Jasrida Yunita ${ }^{2}$ \\ ${ }^{1}$ Dinas Kesehatan Kab. Kuantan Singingi, Riau, Indonesia \\ ${ }^{2}$ STIKes Hang Tuah Pekanbaru, Riau, Indonesia
}

\section{Abstract}

Community participation to join the national health insurance in Kuantan Singingi until December 2014 was 30\% from all population, and 4\% from them were the participant from the informal sectors. The Participant from informal sectors was still little, but the government effort to cover all population before 2019. Many factors related to community participation from informal sectors to join the national health insurance, such as knowledge, attitude, health status, income, cost, and education. This research

Corresponding Author:

Edi Surya

edisurya020@gmail.com

Received: 26 December 2018

Accepted: 23 February 2019

Published: 7 March 2019

Publishing services provided by

Knowledge E

(c) Edi Surya and Jasrida

Yunita. This article is distributed

under the terms of the Creative

Commons Attribution License,

which permits unrestricted use

and redistribution provided that

the original author and source

are credited.

Selection and Peer-review under

the responsibility of the $2 \mathrm{nd}$

International Meeting of Public

Health 2016 Conference

Committee. purposed to determine factors related to community participation from informal sectors to join the national health insurance. This research was quantitative analytical with cross-sectional study design. The population of the research was the informal sector workforce and the sample size was 211 households. Data analysis with univariate, bivariate with Chi-Square test, and multivariate with Multiple Logistic Regression tests. The results showed the informal participants of $\mathrm{NHI}$ that did not join the national health insurance about $67.3 \%$. The factors related with community participation from informal sectors to join the national health insurance consist of Knowledge (POR=14.887), Attitude (POR=4.626), Health Status ( $P O R=172.823)$, Cost ( $P O R=21.594)$, and Education (7.495). The most dominant factor related to the community participation from informal sectors to join the national health insurance is Health Status after being controlled by knowledge, attitude, cost, and education. Be recommended to the Department of Health in District order to improve knowledge about the importance of $\mathrm{NHI}$ programs, assure people to participate in the Membership of $\mathrm{NHI}$ informal sectors programs with involving cross sectors; health center, head of village, BPJS Health, and community leaders, the Health Center to cooperate with authorized institutions in conducting the data collection of the poor to be included as participants $\mathrm{NHI}$ assisted by the Regional Government.

Keywords: Participation of the informal sector; the national health insurance; health status; knowledge; attitude; cost; education 


\section{Introduction}

Indonesia is one of the countries that implement Universal Health Coverage (UHC), which began in 2014. In Indonesia, UHC was known as the National Health Insurance $(\mathrm{NHI})$ or Jaminan Kesehatan Nasional ( JKN). $\mathrm{NHI}$ is organized by the Agency for Providing Health Insurance (BPJS). NHI is part of the National Social Security System (SJSN) with mechanisms of social health insurance. $\mathrm{NHI}$ is compulsory (mandatory) from the Law Number 40/2004 on National Social Security System in Indonesia. The aim is to meet the basic needs of decent public health that is given to every person who has paid contributions or dues paid by the Government. The people who pay contributions coming from self-workers for $\mathrm{NHI}$ was called informal participants of NHI (JKN Mandiri). The goal gives the protective Indonesian people in the insurance system and meet the basic needs of decent public health (Kemenkes RI 2013). Although according to the legislation into NHI participant was required in 2019, the Government of Riau Province to seek the entire community in Riau Province has been a participant $\mathrm{NHI}$ early, before 2019.

According to BPJS, in Indonesia until January 2015 there were 9.8 million participant informality or self-workers pay dues alone. This number increased from the targeted (BeritaSatu.com 2015). Based on data in May 2015 from BPJS Regional Division II Pekanbaru, there are 1.02798 million people as participant $\mathrm{NHI}$ from informal sectors in Riau Province, but they are participants are partly a sick society. The healthy society is still many do not register as a participant (Murti 2014).

Based on the reports from Online Media about participantNHIfrom informal sectors in Kuantan Singingi said that people who follow as participantNHIfrom informal sector still a little than the total population. The participant NHI from informal sectors was 3531 people from 300060 people in 2014. This implies that the knowledge of society in Kuantan Singingi about the importance of health insurance has not been uniformly good. So that, this issue should certainly to study more deeply to purpose the community participation from informal sectors join to the $\mathrm{NHI}$.

Many factors influence a person to guaranteed health care costs. In addition to health status factors, other factors are the level of education, knowledge, attitude, income, and cost (Maharani 2015; Henni 2007).

Based on the early survey to five participants who did not follow participant $\mathrm{NHI}$, there are three people said if they cannot pay dues every month and two people said already have other health insurance so they do not need to be a participant $\mathrm{NHI}$. The results from the survey to five people into a participant $\mathrm{NHI}$ informal sectors said that they enter into the participantNHIbecause of the ailing family members and cared. 
It is necessary to study the participation of informal sector workers/self-workers joins $\mathrm{NHI}$, so it will find the factors are most influential in increasing the participation of the informal sector to join $\mathrm{NHI}$ programs. So the government's target for all the people involved in the membership $\mathrm{NHI}$ can be achieved.

The purpose of this study was to determine the factors related participation of informal sectors to join NHI programs in Teluk Kuantan, Riau, Indonesia.

\section{Methods}

This research is a quantitative analytical with cross-sectional study design. This design can analyze the relationship between several independent variables (knowledge, attitudes, health status, income, cost, and education) with the dependent variable (participation of informal sectors).

The population in this study are the households not classified as civil servants/police/ military and private sector employees who receive the salary from the company or who have their own income in Kuantan Singingi totaling 5.700 households that represented by the head of a family.

The determination of the samples by the formula Lemeshow to see a table size for one sample test of proportion to the level of significance of $5 \%$ and a power of $90 \%$ on one-sided alternative hypothesis (Lemeshow et al. 1990), from the education variable is gotten minimum samples are 211 samples. The sampling procedure is carried out by Systematic Random Sampling in two subdistricts, namely subdistricts highest coverage of $\mathrm{NHI}$ informal sector workforce (District of Kuantan Tengah) and the lowest coverage of participant of $\mathrm{NHI}$ informal sector workforce (District of Kuantan Hilir Seberang).

The data collected comes from questionnaires that had been developed by researcher. So, the questionnaire was tested the validity and reliability. Primary data were collected by interviews with respondents followed the questionnaire format. Variable of participation of informal sectors collected by directly asking respondents about membership. For the participants of $\mathrm{NHI}$ programs, the data collected by observing to the participant of $\mathrm{NHI}$ card to classified as participant informal sector or others. Variable knowledge, attitudes, health status, income, cost, and education are collected by filling in questionnaires by respondents.

Data analysis consisted of univariate, bivariate, and multivariate analysis. Univariate analysis performed to obtain the frequency distribution of each variable research both independent variables and the dependent variable. In addition, to determine the data relatively homogeneous when the proportion is $<15 \%$. Bivariate analysis to find out the significance of the relationship between the independent variables and the dependent 
variable. The bivariate analysis was done by using test $X^{2}$ test. If the result $p<0.05$, it is said that there is a significant relationship between the dependent and independent variables. Multivariate Analysis to determine the effect of independent variables (knowledge, attitudes, social economy, health status, cost, and education) of the dependent variable (participation of informal sectors). Multivariate analysis used in this research is the multiple logistic regression analysis. To determine the level of risk then calculated the results of Prevalence Odd Ratio (POR), namely: $P O R>1$ means a risk factor, $P O R=1$ means, not a risk factor, POR $<1$ means a protective factor (Lapau 2011).

\section{Results and Discussion}

The results of the univariate dependent variables showed that respondents who did not participate in the $\mathrm{NHI}$ programs were $67.3 \%$. For the independent variable showed that respondents with not good knowledge level were 67.3\%; respondents with negative attitudes were $61.1 \%$; respondents with not good health status were $44.1 \%$, respondents with low-income levels were $65.9 \%$; respondents with perception expensive cost were $45.5 \%$, and respondents with low education level were $49.8 \%$.

Bivariate results indicate that all independent variables (knowledge, attitude, health status, income, cost, and related education significantly $(P<0.05)$ with participation of informal sectors(Table 1).

Having obtained the results of the bivariate analysis, the next test was followed by multiple logistic regression test by selecting variables to be included in the model ( $p$ value $\leq 0.25$ ). In bivariate analysis, variables that have obtained $p$ value $\leq 0.25$ is variable knowledge, attitudes, health status, income, cost, and education. Multivariate analysis after modeling was done by issuing a variable one by one and see the changes in the value of POR. The end of modelling could be seen in Table 2 .

The result multivariate analysis in Table 3 could be concluded that the variables were significantly associated with the participation of informal sectors were knowledge, attitude, health status, cost, and education. Income variable was confounder variable to the health status and cost. The results of analysis showed that the most dominant variable related to participation of informal sectors was the health status with $P O R=172.823$. It means the people with the health status of good more risky not to participate as the participant of $\mathrm{NHI}$ programs compared with people with not good status after being controlled by variable knowledge, attitude, cost, and education. 
TABLE 1: Relationship of Independent Variables with Dependent Variable.

\begin{tabular}{|c|c|c|c|c|c|c|c|}
\hline \multirow[t]{3}{*}{ Variable } & \multicolumn{4}{|c|}{ Participant of informal sector } & \multicolumn{2}{|c|}{ Total } & \multirow[t]{3}{*}{ p value } \\
\hline & \multicolumn{2}{|c|}{ Not members } & \multicolumn{2}{|c|}{ Members } & \multirow[b]{2}{*}{$\mathbf{n}$} & \multirow[b]{2}{*}{$\%$} & \\
\hline & $\mathbf{n}$ & $\%$ & $\mathbf{n}$ & $\%$ & & & \\
\hline \multicolumn{8}{|c|}{ Knowledge } \\
\hline Not good & 94 & 72.9 & 35 & 27.1 & 129 & 100 & 0.044 \\
\hline Good & 48 & 58.5 & 34 & 41.5 & 82 & 100 & \\
\hline \multicolumn{8}{|l|}{ Attitude } \\
\hline Negative & 75 & 80.6 & 18 & 19.4 & 93 & 100 & 0.000 \\
\hline Positive & 67 & 56.8 & 51 & 43.2 & 118 & 100 & \\
\hline \multicolumn{8}{|c|}{ Health Status } \\
\hline Good & 126 & 90.6 & 13 & 9.4 & 139 & 100 & 0.000 \\
\hline Not good & 16 & 22.2 & 56 & 77.8 & 72 & 100 & \\
\hline \multicolumn{8}{|l|}{ Income } \\
\hline Low & 76 & 79.2 & 20 & 20.8 & 96 & 100 & 0.001 \\
\hline High & 66 & 57.4 & 49 & 42.6 & 115 & 100 & \\
\hline \multicolumn{8}{|l|}{ Cost } \\
\hline Expensive & 90 & 85.7 & 15 & 14.3 & 105 & 100 & 0.000 \\
\hline Affordable & 52 & 49.1 & 54 & 50.9 & 106 & 100 & \\
\hline \multicolumn{8}{|l|}{ Education } \\
\hline Low & 82 & 89.1 & 10 & 10.9 & 92 & 100 & 0.000 \\
\hline High & 60 & 50.4 & 59 & 49.6 & 119 & 100 & \\
\hline
\end{tabular}

TABLE 2: The end modelling of multivariate.

\begin{tabular}{l|c|c|c|c|} 
Variable & p value & POR & \multicolumn{2}{|c|}{$95 \%$ Cl } \\
\hline Knowledge & & & Lower & Upper \\
\hline Attitude & 0.000 & 14.887 & 3.423 & 64.745 \\
\hline Health Status & 0.013 & 4.626 & 1.379 & 15.520 \\
\hline Income & 0.000 & 172.823 & 32.331 & 923.917 \\
\hline Cost & 0.092 & 2.774 & 0.846 & 9.095 \\
\hline Education & 0.000 & 21.594 & 5.700 & 81.817 \\
\hline
\end{tabular}

\subsection{Related of the health status for the participation of the informal sector to join the NHI programs}

The health status-related with the participation of informal sectors to join $\mathrm{HNI}$ programs. The people opinion with not good health status will risk 172 times to reject into participating in the membership $\mathrm{NHI}$ compared with people with good health status.

Healthy living is a basic need element that always strived to be met regardless of one's ability to pay. People are more inclined to get good health insurance, when they ill and effort to get assurance to be paid individuals or by the government (Henni 2007). 
Based on the Maharani research in 2015 about "Analysis of the Factors that Affect the Community in Singaraja Have Unit link Insurance Program" states that health status about healthy and ill would affect someone in realizing the importance of health insurance. When the disease was more growing and strike a person regardless of age, occupation, place and time. Even critical illness such as stroke, kidney failure, cancer, heart, were not experienced by the elderly but also young people. Not to mention the risk on the road, no one could know. The health status was related to people's interests have Unit link Insurance Program (Maharani 2015).

Health status has confounded with income variable, it means the people with not good health status and had low income would risk being reject into the participation of $\mathrm{NHI}$ programs. Therefore, people with not good health status with low income should be given the understanding by health centers and across sectors such as a head village or head subdistrict to join NHI programs. In addition, the government must be surveyed again to determining the beneficiary community (Penerima Bantuan luran/PBI). So that the informal sector workers who are still low income can be covered in the PBI.

\subsection{Related of cost for participation of the informal sector to join the $\mathrm{NHI}$ programs}

The cost variable related with the participation of informal sectors to join $\mathrm{NHI}$ programs. The people opinion with expensive cost will risk 22 times to reject into participating in the membership $\mathrm{NHI}$ compared with people with low cost.

According to Henni, the monthly dues affects a person/heads family to join the health insurance or choosing health insurance in accordance with their wishes. It depends on a perception of individuals in responding. Fees affordable could make people join the health insurance but the people feel fee of expensive could make them for unfollow the Health Insurance Program (Henni 2007). Yandrizal et al. (2015) research results also get the result that people did not want to pay NHI's dues because of insufficient income. Dartanto et al. (2014) research results concerning about "Expanding universal health Coverage in The Presence of Informal in Indonesia: Challenges and implications" indicate that the Indonesian people have a desire to join the $\mathrm{NHI}$ programs by paying lower premiums. The premium currently seems to be less affordable for them. So, it could create a barrier for the informal sector to work with a new health insurance system.

Cost variable has confounded with income variable, it means the people with highcost perception and had low income would risk rejecting the $\mathrm{NHI}$ programs. For the people who feel cost be expensive must be given the contributions by the local governments so every family gets protection through $\mathrm{NHI}$ programs. 


\subsection{Related of knowledge for the participation of the informal sec- tor to join the NHI programs}

The knowledge related with participation informal sector to join $\mathrm{NHI}$ programs. The people opinion with not good knowledge will risk 15 times to reject into participating in the membership $\mathrm{NHI}$ compared with people with good knowledge.

Knowledge is the result of the idea, and this occurs after a person performs sensing on a specific object. A person without the knowledge does not have a basis for making decisions and decisive action on the problems encountered. Knowledge can be gained from direct experience or from others who come to someone (Notoatmodjo 2007).

In Maslow's Needs contexts said that health is part of the most basic physiological needs in addition to other physiological needs such as eating, drinking, and housing. So, the individual requires a guarantee for their health status. We must give knowledge to people about the $\mathrm{NHI}$ program provided through the provision of information. If the information on the product clearly defined, it can attract the consumer's interest to buy it (Pradipta 2014).

Based on Lukiono research's results about the influence of knowledge and attitudes to use the Health Insurance on Poor Pregnant Women in Kota Blitar showed that there is a significant correlation between the poor pregnant women knowledge against to use of financing childbirth assurance (Lukiono 2010).

The results from Dartanto et al's research about Expanding Universal Health Coverage in The Presence of Informal in Indonesia: Challenges and implications, with the results most important finding, is someone joining BPJS Health is literate insurance, which has a positive effect on willingness to join BPJS Health. If respondents have a basic knowledge of insurance and $\mathrm{NHI}$ programs, the probability to participate in this program will be increased about 0.465 points (Dartanto et al. 2014).

To increase public knowledge about $\mathrm{NHI}$ programs, the health workers need to disseminate and communicate information to the public about the importance of health insurance to anticipate costs that arise later when the community sick and require health services. Information can also be done through the newspaper, leaflets, brochures, and other media. 


\subsection{Related of education for the participation of the informal sec- tor to join the NHI programs}

The education related with participation informal sector to join $\mathrm{NHI}$ programs. The people opinion with low education will risk 7.5 times to reject into participating in the membership $\mathrm{NHI}$ compared with people with high education.

According to Noviansyah et al. (2016), the level of formal education has affected a person's thinking process. Formal education affects health importance. A person with higher education has a higher demand. Higher education will increase awareness of the importance of health insurance. Higher educated society considers important health value, so that will ensure their health to managed by public institutions compared lower educated society (Noviansyah et al. 2016).

The above statement is consistent with Maharani research's results about "Analysis of the Factors that Affect the Community in Singaraja Have Unit link Insurance Program", the findings that there is a significant relationship between education interests have Unit link Insurance Program (Health Insurance). Education is measured by observations of the last diploma owned by individuals (Maharani 2015).

Education is a difficult factor to be modified, so the health workers should actively and continuously provide counseling, especially to the community with low education to think rationally. Health workers can involve community leaders, BPJS Health, the Head of Village and the Head of Subdistrict to actively communicate information about $\mathrm{NHI}$ programs. They must feel responsible for the success of participation of informal sectors to join the $\mathrm{NHI}$ programs. If the all-sector can support increasing membership participation of $\mathrm{NHI}$ programs, so the people with low education can be protected with this health insurance.

\subsection{Related of attitude for participation of the informal sector to join the $\mathrm{NHI}$ programs}

The attitude related to participation informal sector to join $\mathrm{NHI}$ programs. The people opinion with a negative attitude will risk 4,6 times to reject into participating in the membership $\mathrm{NHI}$ compared with people with a positive attitude.

Attitude is a reaction or response was still closed from a person to a stimulus or object. The attitude reflects a person's pleasure or displeasure about something. The attitude comes from experience or from other people familiar with us. They can familiarize us with something or cause us to reject it. If there is a health program that favored the response 
tends positive attitude and a not good health program make the response tends to reject the program (Notoatmodjo 2007).

Based on Purwandari \& Maharani research's result said that the average non PBI informal sector workers support the program NHI (Purwandari \& Maharani 2015). Research Lukiono about the influence of knowledge and attitudes to use the Health Insurance on Poor Pregnant Women in Kota Blitar showed that there was a significant correlation between the negative attitude pregnant women against to use of financing childbirth assurance (Lukiono 2010).

Attitude is a factor that can be modified, so the health workers should continue to motivate households and families in order to become a participant of $\mathrm{NHI}$ programs through counseling by giving examples of the impact to a family. They must pay expensive if they do not guarantee health to cover disease.

\section{Conclusions}

From the results of this study concluded that people who are not participating in the membership NHI informal sectors are about $67.3 \%$. This is caused by the factors of health status, cost, knowledge, education, and attitude. People with good health status assumed cost $\mathrm{NHI}$ expensive, not good knowledge, low education, and have a negative attitude, they have risky to reject in $\mathrm{NHI}$ program.

\section{Suggestions}

Suggestions for this study are expected for the Department of Health in District order to improve knowledge about the importance of $\mathrm{NHI}$ programs as protective of health and also can assure people to participate in the Membership of $\mathrm{NHI}$ informal sectors programs with involving cross sectors; health center, head of village, BPJS Health, and community leaders. Also expected the Department of Health in District through the Health Center to cooperate with authorized institutions in conducting the data collection of the poor to be included as participants NHI assisted by the Regional Government.

\section{References}

[1] BeritaSatu.com. 2015. Akhir Tahun, Peserta BPJS Kesehatan Jadi 168 Juta. Retrieved from www.beritasatu.com.

[2] Dartanto et al. 2014. Expanding Universal Health Coverage in The Presence of Informal in Indonesia: Challenges and Implications. Retrieved fromwww.Ipem.org. 
[3] Henni J. 2007. Asuransi Kesehatan dan Managed Care. 2007. Retrieved from www. pustaka.unpad.ac.id.

[4] Kemenkes RI. 2013. Buku Pegangan Sosialisasi Jaminan Kesehatan Nasional (NHI) dalam Sistem Jaminan Sosial Nasional. Jakarta: Kemenkes RI.

[5] Lapau B. 2011. Metode Penelitian Kesehatan. Jakarta: Yayasan Obor Indonesia.

[6] Lemeshow.S, Hosmer Jr D.W, Klar J, \& Lwanga S.K.1990. Adequacy of Sample Size in Health Studies. New York, USA: WHO.

[7] Lukiono2010. Pengaruh Pengetahuan dan Sikap terhadap Pemanfaatan Jaminan Kesehatan Pada Ibu Hamil Miskin di Kota Blitar. Retrieved fromwww.eprints.uns.ac. id.

[8] Maharani. 2015. Analisis Faktor-Faktor yang Mempengaruhi Masyarakat di Kota Singaraja Memiliki Program Asuransi Unitlink. Retrieved fromwww.ejournal.undiksha. ac.id.

[9] Murti.2014. Peserta BPJS Kesehatan di Riau, Kebanyakan Masyarakat yang Sakit. Retrieved fromwww.bpjs.info.

[10] Notoadmodjo S. 2007. Promosi Kesehatan dan Ilmu Perilaku Manusia. Jakarta: EGC.

[11] Noviansyah et al. 2016. Persepsi masyarakat terhadap Program Jaminan Kesehatan Bagi Masyarakat Miskin. Retrieved fromhttp://download.portalgaruda.org.

[12] Pradipta. 2014. Tinjauan Umum Tentang Asuransi Jiwa dan Faktor Yang Mempengaruhi Seseorang Berasuransi. Retrieved fromhttp://eprints.walisongo.ac.id/.

[13] Purwandari S.I \& Maharani C. 2015. "Analisis Sikap Pekerja Informal Non PBI yang Belum Terdaftar Program Jaminan Kesehatan Nasional (NHI) 2014 di Kabupaten Brebes". Unair Journal of Public Health, Vol 4 No. 2 tahun 2015.

[14] Yandrizal, et al. 2015. Analisis kemampuan dan kemauan membayar iuaran terhadap pencapaian UHC NHI di Kota Bengkulu. Jurnal Kesehatan Masyarakat Andalas, oktober 2015 -maret 2016. vol 10, no. 1 hal 3-10. 